\title{
Presence of Bradyrhizobium sp. under Continental Conditions in Central Europe
}

\author{
Anne Griebsch ${ }^{1, * \mathbb{C}}$, Nicole Matschiavelli ${ }^{2} \mathbb{D}$, Sylwia Lewandowska ${ }^{3}$ and Knut Schmidtke ${ }^{1,4}$ \\ 1 Faculty of Agriculture/Environment/Chemistry, Dresden University of Applied Science, \\ 01069 Dresden, Germany; knut.schmidtke@fibl.org \\ 2 Institute of Resource Ecology, Helmholtz-Zentrum Dresden-Rossendorf, 01328 Dresden, Germany; \\ n.matschiavelli@hzdr.de \\ 3 Department of Genetics, Plant Breeding and Seed Production, Wrocław University of Environmental and \\ Life Sciences, Plac Grunwaldzki 24A, 50-375 Wrocław, Poland; sylwia.lewandowska@upwr.edu.pl \\ 4 Research Institute of Organic Agriculture (FiBL), 5070 Frick, Switzerland \\ * Correspondence: anne.griebsch@htw-dresden.de
}

Received: 27 August 2020; Accepted: 27 September 2020; Published: 30 September 2020

\begin{abstract}
Soil samples from different locations with varied soybean cultivation histories were taken from arable fields in 2018 in East Germany and Poland (Lower Silesia) to evaluate the specific microsymbionts of the soybean, Bradyrhizobium japonicum, one to seven years after inoculation. Soybeans were grown in the selected farms between 2011 and 2017. The aim of the experiment was to investigate whether there is a difference in rhizobia contents in soils in which soybeans have been recultivated after one to seven years break, and whether this could lead to differences in soybean plant growth. The obtained soil samples were directly transferred into containers, then sterilized soybean seeds were sown into pots in the greenhouse. After 94 days of growth, the plants were harvested and various parameters such as the nodular mass, number of nodules, and dry matter in the individual plant parts were determined. In addition, the relative abundances of Bradyrhizobium sp. in soil samples were identified by sequencing. No major decline in Bradyrhizobium sp. concentration could be observed due to a longer interruption of soybean cultivation. Soil properties such as $\mathrm{pH}, \mathrm{P}$, and $\mathrm{Mg}$ contents did not show a significant influence on the nodule mass or number, but seem to have an influence on the relative abundance of Bradyrhizobium sp. The investigations have shown that Bradyrhizobium japonicum persists in arable soils even under Central European site conditions and enters into an effective symbiosis with soybeans for up to seven years.
\end{abstract}

Keywords: Bradyrhizobium sp.; Glycine max; Central Europe; soil properties; Nitrogen concentration nodules; Sulphur concentration nodules

\section{Introduction}

Soybeans are among the most important grain legumes worldwide. In order to meet domestic protein requirements, the area under soybean (Glycine max (L). Merr.) cultivation in Germany has increased in recent years (2019: $29.200 \mathrm{ha} ;+21.2 \%$ previous year) [1]. In order to fix nitrogen symbiotically and exploit soybeans' yield potential, soybeans live in obligatory symbiosis with the bacterium Bradyrhizobium japonicum. However, B. japonicum is not native to Central European soils. For this reason, soybeans are usually inoculated with $B$. japonicum before sowing under Central European conditions. There are various preparations available in liquid or powder form, which are added to the seeds directly before sowing. Narzona et al. [2] showed in a field experiment that soybean-specific $B$. japonicum strains survived for at least 20 years after being introduced into the soil as inoculum in Poland. Here, B. japonicum was detected at a maximum distance of $40 \mathrm{~m}$ from the original 
inoculation area, indicating that the mobility of B. japonicum is very limited, despite an intensive tillage system. Brunel et al. [3] also found that B. japonicum survived in soil for more than 10 years, although soybeans were not cultivated during this period. Obaton et al. [4] demonstrated the occurrence of B. japonicum in Dijon (France) after 20 years without soybean cultivation. However, for effective nodulation, the authors suggest re-inoculation after a cultivation break of 5 years. Additionally, Triplett et al. [5] confirmed a high persistence of B. japonicum in silty loam soils and concluded that re-inoculation within five years is not necessary. In addition, it was proven that the soybean cultivation frequency and the time since the crop has been grown at the respective site have an influence on the number of bacteria population [6]. The study recommends re-inoculation for a new soybean crop after 5.5 to 18 years, as a decrease in the B. japonicum population was observed in soil after this period.

Various studies have shown that soil properties also influence the survival and efficiency of nodule bacteria. Buendía-Clavería et al. [7] were able to demonstrate differences in nodule formation as a function of $\mathrm{pH}$ and the specific rhizobium. For example, $B$. japonicum can form more nodules on acidic soils ( $\mathrm{pH}$ 4.9) than Rhizobium fredii. In contrast, $R$. fredii is more competitive in alkaline soils (pH 8.1). Both nodule bacteria are considered suitable for soybean cultivation in Europe. Revellin et al. [6] also described that various biotic and abiotic factors influence the survival of B. japonicum. In this context, they showed that there is no clear relation between the $\mathrm{pH}$ and nodule number, but calcareous soils with a high $\mathrm{pH}$ represent a less favorable environment in terms of the rhizobia's ability to survive than other soils. Furthermore, the results suggest that phosphorus availability is not a limiting factor for the growth and survival of B. japonicum. Additionally, Weaver et al. [8] showed that soil texture and $\mathrm{pH}$ (5.6-8.2) do not have a significant influence on the number of soybean rhizobia. In addition, there is evidence that $B$. japonicum shows higher nodule formation at low temperatures than other Rhizobium strains $[9,10]$. This is the reason why B. japonicum is mainly used for inoculation in Central European soils.

Soybeans are generally grown as the main crops in Germany and Poland. Intercropping of soybeans is not common, as the seed is expensive. However, there are some farmers who grow soybeans as an intercrop to achieve a better distribution of B. japonicum in the soil.

The research questions to be answered in this paper are:

Various studies have already shown that B. japonicum can survive in soil in Poland and France. The aim of this study is to test the extent to which soybean-specific rhizobia can survive under the conditions of East Germany and Lower Silesia, even after a longer cultivation break.

How do soil properties influence the presence of introduced B. japonicum strains?

Do nodule growth and shoot dry matter differ if the last soybean cultivation with inoculation took place one to seven years ago?

\section{Materials and Methods}

\subsection{Soil Samples and Experimental Design}

After a small preliminary experiment for the test setup and execution, as well as an adjustment of the test procedure in spring 2017, the soil samples were taken in early March 2018 from 47 different fields of 14 farms located in Saxony, Saxony-Anhalt, and Brandenburg in Germany and Lower Silesia in Poland. Additionally, samples were taken from trial plots with soybean catch crop cultivation from Dresden University of Applied Science in Dresden-Pillnitz and the Wroclaw University of Environmental and Life Sciences (Poland) from $0-0.15 \mathrm{~m}$ soil depth. The fields have been cultivated conventionally or organically for many years, with soybean crops grown either once or in two consecutive years between 2011 and 2017. Each farm used inoculation with a B. japonicum vaccine preparation for soybean cultivation (e.g., HiStick, Biodoz, Rhizolik tops). The main soybean crops achieved average grain yields of $1.81 \mathrm{t} \mathrm{ha}^{-1}$ in organic and $2.75 \mathrm{t} \mathrm{ha}^{-1}$ in conventional cultivation (Table 1). Typical follow-up crops were often winter wheat, maize, or winter rye. Soil samples were taken by a soil sampling auger (operating length $0.15 \mathrm{~m} ; \varnothing 0.08 \mathrm{~m}$ ) at all farms in spring 2018 . 
Sampling was carried out at the farms according to the cultivation history, starting with the sampling of the longest past cultivation of soybean. At each site, 15 punctures were made, so that a mixed sample of about $12 \mathrm{~kg}$ of soil material was obtained per field. The equipment was cleaned with water and sodium hypochlorite between each sampling. Due to the high humidity of the soil at the time of sampling in the field, the samples from Poland were gently dried in a drying cabinet at $21^{\circ} \mathrm{C}$ for $48 \mathrm{~h}$. A basic chemical analysis was carried out on each soil sample in accordance with the guidelines for soil analysis of the Association of German Agricultural Analytic and Research Institutes e. V. (VDLUFA). The $\mathrm{pH}$ values [11] and the phosphorus (P), potassium (K) [12], magnesium (Mg) [13], humus [14], and total nitrogen $\left(\mathrm{N}_{\mathrm{t}}\right)$ contents $[15,16]$ were determined accordingly (Table 1). For better classification of the different soils, the soil texture, soil index, and yield of the soybean harvest in this area are given. In Germany, the soil index is a comparative system for assessing soil quality, with scores ranging from 0 (very low) to 100 (high). This ratio is intended to express differences in yield, which under otherwise equal conditions, can only be explained by natural soil properties [17]. Buckets and shovels that were cleaned with water and disinfected (sodium hypochlorite) were used to prepare the soil, and new nitrile gloves were used for each sample. Every soil sample (one sample was around $12 \mathrm{~kg}$ ) was mixed with non-sterile building sand $(0-2 \mathrm{~mm} ; \mathrm{N}(\%)=0.004, \mathrm{C}(\%)=0.022)$ at a ratio of $3: 1$ and transferred to four disinfected pots (sodium hypochlorite, four replicates per field sample) (V 5.5 l; $\varnothing 20 \mathrm{~cm} ; \mathrm{H} 25.5 \mathrm{~cm}$ ). To prevent the transmission of bacteria through irrigation, a plastic bag $(3 \mathrm{~L})$ was used for covering each pot. Five sterilized seeds of cv. Merlin (not genetically modified) were sown in each pot. Seed sterilization was performed with $3 \%$ sodium hypochlorite. The seeds were placed in a beaker with sodium hypochlorite for $20 \mathrm{~min}$. In the next step, the seeds were rinsed three times with sterile distilled water for five minutes. The seeds were put on paper to dry. The pots were placed in the greenhouse in a random arrangement, depending on the operation. There were three different types of controls: a field control from the experimental plot in Pillnitz, which had no history of soybean cultivation and had never been inoculated (C BW); along with an uninoculated (C uI) and an inoculated (C I) control (HiStick, BASF) consisting of a mixture (3:1) of non-sterile raised bog peat base (BRiLL Bio Herb Mix: pH $5.9\left(\mathrm{CaCl}_{2}\right)$, S 0.9 g/L KCI, N 80 mg/L CaCl, P 120 mg/L CAL, K 450 mg/L $\mathrm{CAL}, \mathrm{Mg} 120 \mathrm{mg} / \mathrm{L} \mathrm{CaCl}_{2}$ ) and sand.

Each variation had four replications, thus the experiment involved 224 containers (summarized below): three different controls (C BW, C uI, C I), 46 field samples after soybean main crops from farms, six different soil samples from intercropping field experiments with soybeans (with and without inoculation) from Dresden and Wroclaw, as well as one sample from an intercrop trial with soybeans from a farm. 
Table 1. Characterization of the soil samples used.

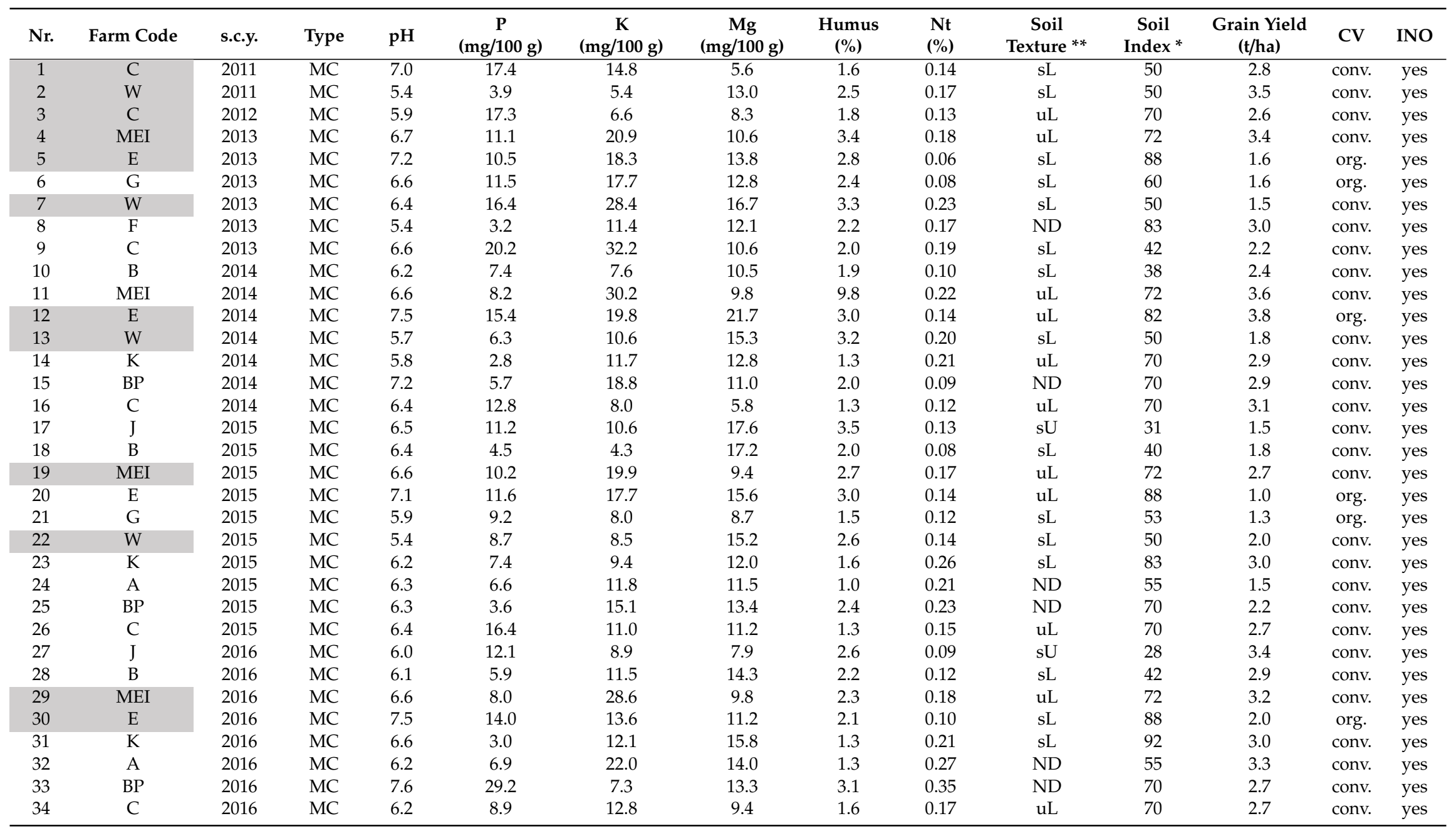


Table 1. Cont.

\begin{tabular}{|c|c|c|c|c|c|c|c|c|c|c|c|c|c|c|}
\hline Nr. & Farm Code & s.c.y. & Type & $\mathrm{pH}$ & $\begin{array}{c}P \\
(\mathrm{mg} / 100 \mathrm{~g})\end{array}$ & $\begin{array}{c}\mathrm{K} \\
(\mathrm{mg} / 100 \mathrm{~g})\end{array}$ & $\begin{array}{c}\mathrm{Mg} \\
(\mathrm{mg} / 100 \mathrm{~g})\end{array}$ & $\begin{array}{c}\text { Humus } \\
(\%)\end{array}$ & $\begin{array}{l}\mathrm{Nt} \\
(\%)\end{array}$ & $\begin{array}{c}\text { Soil } \\
\text { Texture ** }\end{array}$ & $\begin{array}{c}\text { Soil } \\
\text { Index }\end{array}$ & $\begin{array}{l}\text { Grain Yield } \\
\text { (t/ha) }\end{array}$ & CV & INO \\
\hline 35 & $\mathrm{~J}$ & 2017 & $\mathrm{MC}$ & 6.7 & 13.1 & 15.9 & 10.4 & 2.9 & 0.13 & $\mathrm{sU}$ & 28 & 3.5 & conv. & yes \\
\hline 36 & $\mathrm{P}$ & 2017 & $\mathrm{MC}$ & 6.7 & 4.3 & 6.3 & 15.1 & 2.1 & 0.10 & $\mathrm{tL}$ & 60 & 4.2 & conv. & yes \\
\hline 37 & B & 2017 & $\mathrm{MC}$ & 6.6 & 5.7 & 5.3 & 11.2 & 2.1 & 0.15 & sL & 42 & 3.5 & conv. & yes \\
\hline 38 & MEI & 2017 & MC & 7.1 & 9.9 & 22.1 & 9.1 & 1.6 & 0.08 & $\mathrm{uL}$ & 72 & 3.2 & conv. & yes \\
\hline 39 & $\mathrm{E}$ & 2017 & $\mathrm{MC}$ & 7.5 & 18.2 & 13.0 & 24.1 & 3.5 & 0.19 & $\mathrm{~L}$ & 88 & 1.6 & org. & yes \\
\hline 40 & G & 2017 & MC & 6.2 & 13.0 & 27.6 & 11.7 & 2.2 & 0.11 & sL & 50 & 1.5 & org. & yes \\
\hline 41 & W & 2017 & MC & 6.0 & 5.0 & 9.0 & 18.5 & 2.5 & 0.17 & sL & 50 & 4.0 & conv. & yes \\
\hline 42 & K & 2017 & MC & 7.1 & 5.6 & 8.5 & 11.7 & 1.3 & 0.14 & sL & 57 & 2.9 & conv. & yes \\
\hline 44 & F & 2017 & $\mathrm{MC}$ & 7.1 & 7.0 & 13.4 & 10.2 & 3.3 & 0.33 & ND & 83 & 2.8 & conv. & yes \\
\hline 45 & BP & 2017 & MC & 6.8 & 15.1 & 21.7 & 3.3 & 2.1 & 0.08 & ND & 50 & 2.9 & conv. & yes \\
\hline 46 & C & 2017 & MC & 5.7 & 20.0 & 7.8 & 11.1 & 1.3 & 0.20 & $\mathrm{uL}$ & 70 & 2.4 & conv. & yes \\
\hline 47 & $\mathrm{bp}$ & 0 & c & 5.9 & 2.5 & 7.5 & 16.1 & 10.7 & 0.16 & ND & ND & - & conv. & no \\
\hline 48 & $\mathrm{Wr}$ & $17 / 18$ & IC & 5.8 & 4.8 & 10.6 & 11.7 & 5.8 & 0.09 & $\mathrm{sL}$ & 70 & - & conv. & yes/no \\
\hline 49 & $\mathrm{Pi}$ & $17 / 18$ & IC & 6.9 & 6.7 & 12.3 & 13.9 & 2.6 & 0.12 & sL & 65 & - & org. & yes/no \\
\hline 50 & W & $17 / 18$ & IC & 5.5 & 5.6 & 12.7 & 14.9 & 5.2 & 0.49 & sL & 50 & - & conv. & yes \\
\hline
\end{tabular}

Farm code: $\mathrm{C}=$ Sroda Slaska, $\mathrm{W}=$ Waldenburg, MEI = Meißen, $\mathrm{E}=$ Edlau, $\mathrm{G}=$ Görlitz, $\mathrm{F}=$ Rzeplin, B = Bauda, $\mathrm{K}=\mathrm{Zwanowice,} \mathrm{BP}=\mathrm{Lewin}$ Brzeski, $\mathrm{J}=\mathrm{Jänkendorf,} \mathrm{A} \mathrm{=} \mathrm{Miekinia,}$

$\mathrm{bp}=$ bog peat, $\mathrm{Wr}=$ Wroclaw, $\mathrm{Pi}=$ Pillnitz; s.c.y. = soybean cultivation year; $\mathrm{MC}=$ main crop; $\mathrm{c}=$ control; $\mathrm{IC}=$ intercrop; $\mathrm{ND}=$ not determined; $\mathrm{CV}=\mathrm{cultivation}, \mathrm{conv}$. $=$ conventional, org. = organic; INO = inoculation; ** soil texture according to LUFA [18], sL = sandy loam, $\mathrm{uL}=$ silty loam, $\mathrm{sU}=$ sandy silt, $\mathrm{tL}=$ clayey loam, $\mathrm{L}=$ loam; ${ }^{*}$ soil index converted as per LINK et al. [19], since the scale for the soil index in Poland ranges from 18 to 100; shaded cells = samples for DNA sequencing. 
The plants were watered with non-sterile tap water as needed and grown under long daytime conditions consisting of $16 \mathrm{~h}$ of light and $8 \mathrm{~h}$ of darkness. The observed average air temperature was $20.8^{\circ} \mathrm{C}$ and the humidity was $56.2 \%$. After 14 days, the first seedlings of the soybean germinated. In some cases, the pots had to be reseeded because the seeds had not germinated sufficiently the first time. Again, sterile conditions were maintained and new nitrile gloves were used for each pot. Later, the number of plants was reduced to two per pot. In some pots only one plant survived. This was mainly the case for samples from the experimental plots in Pillnitz and Wroclaw. On three dates (23 May, 1 June, and 16 June), the chlorophyll content was measured with a chlorophyll meter (SPAD-502Plus). Six measurements per pot were recorded. For each plant, two values were measured on the lowest, middle, and youngest fully developed leaves. The plants were harvested in mid-June, 94 days after sowing. At that time, the first pods were partially visible on the plants. At harvest, all four repetitions of a sample were always processed in succession. Furthermore, a mixed sample of the soil was taken from all four replicates for later sequencing and stored at $-18{ }^{\circ} \mathrm{C}$ until analysis. Each mixed sample was taken with new nitrile gloves and transferred into sterile tubes $(50 \mathrm{~mL}, 114 \times 28 \mathrm{~mm}$, PP, SARSTEDT). The number of samples for sequencing was limited to 17 samples. This means that two samples from the intercrop experiments without and with inoculation of the intercrop were included, as well as 15 samples from farms that cultivated soybeans between 2011 and 2017. In order to obtain the best possible overview, at least two samples were selected from each year in which soybeans were last grown in the fields. This was not possible for the harvest year 2012, as there was only one farmer who had grown soybeans in this year. In addition, we attempted to select samples from the same farms in order to reduce the influence of the different cultivation methods. The plants were carefully removed from the pots and the soil adhering to the roots was rinsed under clear water. The plant roots and shoot mass were subsequently separated. The nodules were removed from the roots by hand and counted. In the next step, the samples were dried and weighed at $55^{\circ} \mathrm{C}$ for $48 \mathrm{~h}$. Elemental analysis (EuroEA3000-Hekatech) was used to determine the contents of total nitrogen $(\mathrm{N})$ and sulfur (S) in nodules, roots, and shoots (chromatographic separation of the oxidation gases). For this purpose, the samples were ground to a particle size of $\leq 0.2 \mathrm{~mm}$, the material was filled into $3 \times 6 \mathrm{~mm}$ tin capsules (IVA Analysentechnik, Meerbusch), then weighed with a fine balance (Mettler Toledo XA 105 Dual Range) with an accuracy of $\pm 0.01 \mathrm{mg}$. The amount weighed was based on the carbon/nitrogen ratio of the plant material, which ranged from 2.8 to $3.0 \mathrm{mg}$ for soybeans. For the determination of the sulfur content, about 7 to $10 \mathrm{mg}$ vanadium pentoxide was added to the sample

\subsection{Extraction, Purification and Sequencing of DNA from Soil Samples}

For analysis of the microbial diversity in the respective soil samples, DNA was extracted by using a DNeasy PowerSoil Kit (Quiagen, Hilden, Germany) following the instruction manual. For the final elution of DNA, $60 \mu \mathrm{L}$ sterile and double-filtrated water was used. The extracted DNA was utilized for amplification of the V4 region of the 16S rRNA gene by using PCR [20]. The PCR reactions contained $25 \mu \mathrm{L}$ PCR water, $5 \mu \mathrm{L} \mathrm{MgCl}_{2}$ (2.5 mM final concentration), $10 \mu \mathrm{L} 5 \times$ buffer (Promega, Madison, WI, USA), $2.0 \mu \mathrm{L}$ each of oligonucleotides 515f (GTGCCAGCMGCCGCGGTAA) and 806r (GGACTACHVGGGTWTCTAAT) [21] at $0.4 \mu \mathrm{M}$ final concentration, $0.5 \mu \mathrm{L}$ dNTPs (desoxy nucleoside triphosphates (stock solution of dATP, dGTP, dCTP and dTTP; final concentration in stock is each $12.5 \mathrm{mM}$ )), $0.5 \mu \mathrm{L}$ Taq-Polymerase (Promega, $0.05 \mathrm{U} / \mu \mathrm{L}$ final concentration), and $5 \mu \mathrm{L}$ genomic DNA. Reactions were held at $95^{\circ} \mathrm{C}$ for $2 \mathrm{~min}$ to denature the DNA, with amplification proceeding for 30 cycles at $95{ }^{\circ} \mathrm{C}$ for $30 \mathrm{~s}, 50{ }^{\circ} \mathrm{C}$ for $60 \mathrm{~s}$, and $72{ }^{\circ} \mathrm{C}$ for $60 \mathrm{~s}$. A final step of $10 \mathrm{~min}$ at $72{ }^{\circ} \mathrm{C}$ was added to th procedure to ensure complete amplification. Successfully amplified DNA was purified with MSB ${ }^{\circledR}$ Spin PCRapace (Stratec Molecular, Berlin, Germany) according to the manufacturer's protocol. For the final elution of DNA, $22 \mu \mathrm{L}$ of sterile and double-filtrated water was used. Purified amplicons were quantified with a Qubit 4 (Thermo Scientific ${ }^{\mathrm{TM}}$, Waltham, MA, USA) and quality control was achieved by using a NanoDrop ${ }^{\mathrm{TM}}$ (Thermo Scientific ${ }^{\mathrm{TM}}$ ) following the manufacturer's protocol. The samples were sequenced with MiSeq Illumina at RTL Genomics (Lubbock, TX, USA). Data analysis was undertaken 
following the guidelines of RTL Genomics [22]. The retrieved 16S rRNA gene sequences are available at the NCBI database with the bioproject accession number PRJNA663446.

\subsection{Statistical Analysis}

Analysis was conducted using the statistical analysis system (SAS) program version 9.3 of SAS Institute Inc., Cary, NC, USA (2013). A Tukey's test, Kruskal-Wallis test, and Pearson's correlation analysis were performed. Differences between treatments were significant or not at $5 \%$ for all sets of data analyzed.

\section{Results}

\subsection{Influence of Soil Properties on Nodule and Plant Growth}

In order to investigate the influence of distinct soil parameters on the amount of rhizobia and on the mass and number of nodules, a basic nutrient analysis of the soil was carried out. No significant correlations between the parameters of the basic soil nutrient analysis and the nodule number, nodular mass, and the nodule nitrogen $(\mathrm{N})$ concentration were found. One exception was the weakly to moderately significant correlation between humus and nitrogen values (Table 2). A high humus content seemed to have a positive effect on nodule development. There was a weakly significant correlation between the nodule $\mathrm{N}$ concentration and humus content $(\mathrm{r}=0.32)$. The phosphorus concentration $(\mathrm{P})$ $(r=0.27)$ and the humus content $(r=0.29)$ had a weak influence on the nodule mass, which was not significant. The total nitrogen content $\left(\mathrm{N}_{\mathrm{t}}\right)$ in the soil had a negative weakly significant influence on the number of nodules $(\mathrm{r}=-0.30)$ and the nodular mass $(\mathrm{r}=-0.31)$. A breakdown of the data according to groups with $\mathrm{pH}<6$ and $\mathrm{pH}>6$ also exhibited no significant results. There was a medium relationship between the $\mathrm{pH}$ value and root dry mass $(\mathrm{r}=0.49)$, as well as between the $\mathrm{pH}$ value and number of nodules $(\mathrm{r}=0.38)$ at $\mathrm{pH}<6$. No significant correlations could be found at $\mathrm{pH}>6$, however the number of samples at $\mathrm{pH}<6(\mathrm{~N}=11)$ was smaller than at $\mathrm{pH}>6(\mathrm{~N}=35)$.

Table 2. Correlation of soil parameters with nodule number, nodular mass, and nodular N concentration per plant (arithmetic mean of four replicates per pot).

\begin{tabular}{lcccccc}
\hline & $\mathbf{p H}$ & $\mathbf{P}$ & $\mathbf{K}$ & $\mathbf{M g}$ & Humus & $\mathbf{N}_{\mathbf{t}}$ \\
\hline Number of nodules & -0.15 & -0.06 & 0.00 & -0.19 & 0.12 & $-0.30 *$ \\
Nodular mass & 0.03 & 0.27 & 0.01 & -0.11 & 0.29 & $-0.31 *$ \\
N concentration & 0.12 & 0.08 & 0.04 & 0.01 & $0.32 *$ & -0.25 \\
\hline
\end{tabular}

Normal distribution is given according to Shapiro-Wilk test and Pearson's correlation test at $p<0.05$. Components of variation: ${ }^{*}$, significance at the $p<0.05$, respectively.

\subsection{Sequencing Results}

The sequencing results of DNA from random samples from the different soils are illustrated in Figure 1. In this context, the relative abundance levels of Bradyrhizobium sp. in soil samples from 17 different sites are compared. Additional data are given in Figure S1 and Table S1 (Supplementary Materials). The inoculated peat (HiStick $10^{9}$ vital cells) served as a reference value and had a relative abundance of $99.62 \%$ Bradyrhizobium sp. The highest relative abundances of rhizobia were found in soil samples from 2011 (no. 2) and 2015 (no. 22), which were both 2.89\%. This means that no soybeans had grown in these soil samples for seven and three years, respectively. This was followed by soil samples from 2014 (no. 13, 2.83\%) and 2013 (no. 4, 2.68\%). High values of rhizobia were observed in three of four samples from the location in Waldenburg. In contrast, the soil samples from the farm in Edlau showed a low relative abundance of Bradyrhizobium sp. In this context, it should be noted that with increasing $\mathrm{pH}$ values and $\mathrm{P}$ concentrations in the soil, the relative abundances of Bradyrhizobium sp. decreased $(\mathrm{r}=-0.86 ; \mathrm{r}=-0.63)$. Likewise, the $\mathrm{K}$ concentrations $(\mathrm{r}=-0.44)$ and the $\mathrm{Mg}$ contents $(r=-0.27)$ in the soil influenced the relative abundances of the rhizobia. However, these values must 
be examined carefully and only represent tendencies, as the sample size was very small. Over the years, the rhizobia were evenly distributed, indicating that they can tolerate longer breaks in soybean cultivation. Taking into account the sample size and data quality, the results suggest that the soil properties influence nodule formation less than the relative abundance of Bradyrhizobium sp.

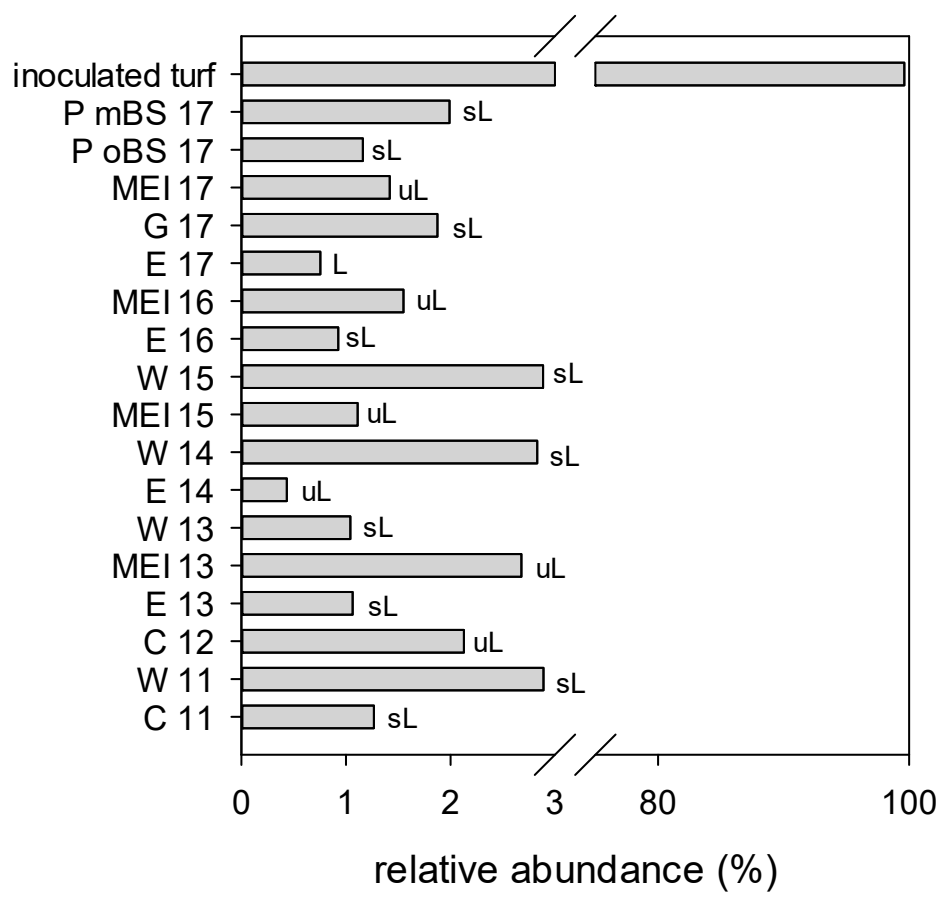

Figure 1. Relative abundance of Bradyrhizobium sp. in selected soil samples. P = Pillnitz; o = without inoculation; $\mathrm{m}=$ with inoculation; $\mathrm{BS}=$ buckwheat and soybean as intercropping; $\mathrm{MEI}=$ Meißen; $\mathrm{G}=$ Görlitz; $\mathrm{E}=$ Edlau; $\mathrm{W}=$ Waldenburg; $\mathrm{C}=$ Poland; $\mathrm{sL}=$ sandy loam; $\mathrm{uL}=$ silty loam; $\mathrm{L}=$ loam.

\subsection{Plant Growth and Nutrient Concentration}

Table 3 lists the average nodular mass, number of nodules, as well as the root and shoot dry mass per plant in different soil samples after a break in soybean cultivation and after different kinds of intercropping. The results from the field control (C BW) reveal the strongest root and shoot growth despite having very few nodules compared to the years of the last soybean cultivation between 2011 and 2017. The control with inoculation (C I) developed almost five times more nodules, but otherwise do not differ significantly from the control without inoculation $(\mathrm{C} \mathrm{uI})$. Looking at the results obtained in 2014 and 2017, there was a significant difference in the numbers of nodules $(p=0.02)$ and root dry mass values $(p=0.03)$. The number of nodules was higher in 2017 , but the dry root mass was lower than in 2014. Apart from these criteria, the years do not differ significantly from each other. Only the field control (C BW), where soybeans had never been cultivated before, showed significant differences compared to soil samples after cultivation breaks. This result indicates that inoculation might be useful for first time cultivation. 
Table 3. Average plant dry matter of soybean (one sample = mean value of four replications) in different soil samples after soybean cultivation breaks and after different kinds of intercropping $( \pm \mathrm{SD}=$ standard deviation).

\begin{tabular}{|c|c|c|c|c|}
\hline Sample & $\begin{array}{l}\text { Nodule Weight } \\
\text { (g plant }^{-1} \text { ) }\end{array}$ & $\begin{array}{c}\text { Nodules } \\
\text { (Number plant }^{-1} \text { ) }\end{array}$ & $\begin{array}{l}\text { Root Weight } \\
\text { (g plant }^{-1} \text { ) }\end{array}$ & $\begin{array}{l}\text { Shoot Weight } \\
\left.\text { (g plant }^{-1}\right)\end{array}$ \\
\hline \multicolumn{5}{|l|}{ control } \\
\hline $\mathrm{CuI}$ & $0.0799( \pm 0.03)$ & $12.0( \pm 7.3)$ & $0.4( \pm 0.35)$ & $2.3( \pm 0.68)$ \\
\hline C I & $0.0919( \pm 0.02)$ & $57.7( \pm 22.8)$ & $0.4( \pm 0.12)$ & $4.6( \pm 1.12)$ \\
\hline C BW & $0.0037( \pm 0.01)$ & $0.2( \pm 0.7)$ & $0.8( \pm 0.32)$ & $6.3( \pm 1.88)$ \\
\hline \multicolumn{5}{|l|}{ year } \\
\hline $2011[\mathrm{~N}=2]$ & $0.0785( \pm 0.02)$ & $33.2( \pm 12.4)$ & $0.5( \pm 0.17)$ & $3.7( \pm 0.53)$ \\
\hline $2012[\mathrm{~N}=1]$ & $0.1565( \pm 0.02)$ & $32.7( \pm 19.8)$ & $0.6( \pm 0.24)$ & $5.0( \pm 0.63)$ \\
\hline $2013[\mathrm{~N}=6]$ & $0.1061( \pm 0.03)$ & $29.7( \pm 11.0)$ & $0,4( \pm 0.08)$ & $4.1( \pm 0.64)$ \\
\hline $2014[\mathrm{~N}=7]$ & $0.0910( \pm 0.03)$ & $21.0( \pm 7.5)$ & $0.5( \pm 0.12)$ & $4.1( \pm 0.64)$ \\
\hline $2015[\mathrm{~N}=9]$ & $0.0918( \pm 0.04)$ & $28.9( \pm 13.5)$ & $0.4( \pm 0.13)$ & $3.7( \pm 0.66)$ \\
\hline $2016[\mathrm{~N}=9]$ & $0.0877( \pm 0.03)$ & $24.3( \pm 10.2)$ & $0.4( \pm 0.14)$ & $4.0( \pm 0.59)$ \\
\hline $2017[\mathrm{~N}=12]$ & $0.0929( \pm 0.03)$ & $36.7( \pm 13.4)$ & $0.4( \pm 0.15)$ & $4.2( \pm 0.97)$ \\
\hline \multicolumn{5}{|l|}{ intercrop } \\
\hline Wr oS & $0.0942( \pm 0.06)$ & $9.3( \pm 10.1)$ & $0.7( \pm 0.31)$ & $3.8( \pm 0.42)$ \\
\hline Wr mS & $0.1210( \pm 0.01)$ & $29.1( \pm 1.9)$ & $0.3( \pm 0.11)$ & $4.1( \pm 0.50)$ \\
\hline $\mathrm{P}$ oS & $0.0533( \pm 0.04)$ & $13.5( \pm 12.2)$ & $0.7( \pm 0.33)$ & $5.0( \pm 2.00)$ \\
\hline $\mathrm{P} \mathrm{mS}$ & $0.1745( \pm 0.11)$ & $56.2( \pm 53.6)$ & $1.0( \pm 0.61)$ & $7.1( \pm 2.31)$ \\
\hline P oBS & $0.0632( \pm 0.04)$ & $13.2( \pm 9.9)$ & $0.8( \pm 0.43)$ & $6.4( \pm 2.87)$ \\
\hline P mBS & $0.0862( \pm 0.05)$ & $13.3( \pm 6.2)$ & $0.6( \pm 0.24)$ & $6.4( \pm 1.38)$ \\
\hline W IC & $0.1391( \pm 0.03)$ & $18.8( \pm 8.2)$ & $0.7( \pm 0.15)$ & $5.1( \pm 0.99)$ \\
\hline
\end{tabular}

$\mathrm{C} \mathrm{uI}=$ control with cultivated soil without inoculation; $\mathrm{CI}=$ control with cultivated soil and inoculation; $\mathrm{C}$ BW $=$ field control without inoculation; $\mathrm{Wr}=$ Wroclaw; $\mathrm{P}=$ Pillnitz; $\mathrm{o}=$ without inoculation; $\mathrm{m}=$ with inoculation; $\mathrm{S}=$ soybean as intercropping; BS = buckwheat and soybean as intercropping; W IC = Waldenburg intercrop.

Significant differences between the inoculated and non-inoculated soybean plants can be seen in the samples taken after intercropping (Table 3). The inoculated soybean show a higher nodular mass and number of nodules compared to the non-inoculated plants. However, this is not the case with the number of nodules of the BS samples. These differ only in the nodule mass, which suggests an effect of buckwheat on soybean growth. Furthermore, the root and shoot dry matter in the soybean-buckwheat intercrop differed significantly from that of sole crop in Wroclaw and the controls. In addition to the experimental plots in Pillnitz and Wroclaw, there was also a sample from a farm (W IC) where soybeans were grown as a catch crop, which were inoculated. With an average of 18.8 nodules per plant, the number of nodules for this variant was comparable with the non-inoculated variants at the Pillnitz and Wroclaw sites. In contrast, with an average of $0.1391 \mathrm{~g} / \mathrm{plant}$, the nodular mass had the second highest weight of all intercrop variants. The root and shoot dry matter had weights of $0.73 \mathrm{~g} /$ plant and $5.1 \mathrm{~g} / \mathrm{plant}$, respectively, which were in the middle of the range. This indicates that a few large nodules were more efficient than many small ones, which is confirmed by the data in Table 4 .

Table 4. Correlation between the nodule numbers, nodular mass and dry matter values, as well as the nitrogen concentrations of soybean plants (mean values of four replicates).

\begin{tabular}{lccccc}
\hline & $\begin{array}{c}\mathbf{D M}_{\text {root }} \\
\left.\text { (g plant }^{-1}\right)\end{array}$ & $\begin{array}{c}\mathbf{D M}_{\text {shoot }} \\
\left.\text { (g plant }^{-1}\right)\end{array}$ & $\mathbf{N}_{\text {root }}(\mathbf{\%})$ & $\mathbf{N}_{\text {shoot }}(\mathbf{\%})$ & $\mathbf{N}_{\text {nodules }}$ (\%) \\
\hline number of nodules & 0.18 & $0.57^{* * *}$ & -0.25 & 0.29 & 0.29 \\
nodular mass & $0.54^{* * *}$ & $0.88^{* * *}$ & $-0.36^{*}$ & 0.21 & $0.44^{* *}$ \\
\hline
\end{tabular}

Normal distribution is given according to Shapiro-Wilk and Pearson's correlation tests at $p<0.05$. Components of variation: $* * *, * *$ significance at the $p<0.05,0.01$, and 0.001 levels, respectively. $\mathrm{DM}=$ dry matter; $\mathrm{N}=$ itrogen concentration. 
The $\mathrm{N}$ concentrations in roots, shoots, and nodules are shown in Figure 2. In this context, the nodules had the highest $\mathrm{N}$ contents, whereas shoot and roots had the lowest contents. The nodules were very rich in nitrogen, with an average value of $6.27 \%$. Nodules on plants grown in soils from farmers' fields were slightly lower in $\mathrm{N}(6.23 \%)$ than samples from intercropping experiments $(6.60 \%)$. This could be due to the fact that the intercrop soybean crops were only cultivated the year before. Furthermore, if the intercrop is well established, this can ensure a good distribution of the rhizobia in the soil, which can also be seen from the high nodule mass and good plant growth values from the practical intercrop trial. In intercropping samples, a difference between the inoculated and non-inoculated varieties can be seen. The $\mathrm{N}$ concentrations in the inoculated variants were higher than in the uninoculated ones, which indicates that the inoculated plants were able to form more nodules, and therefore the fixation of atmospheric nitrogen was improved.
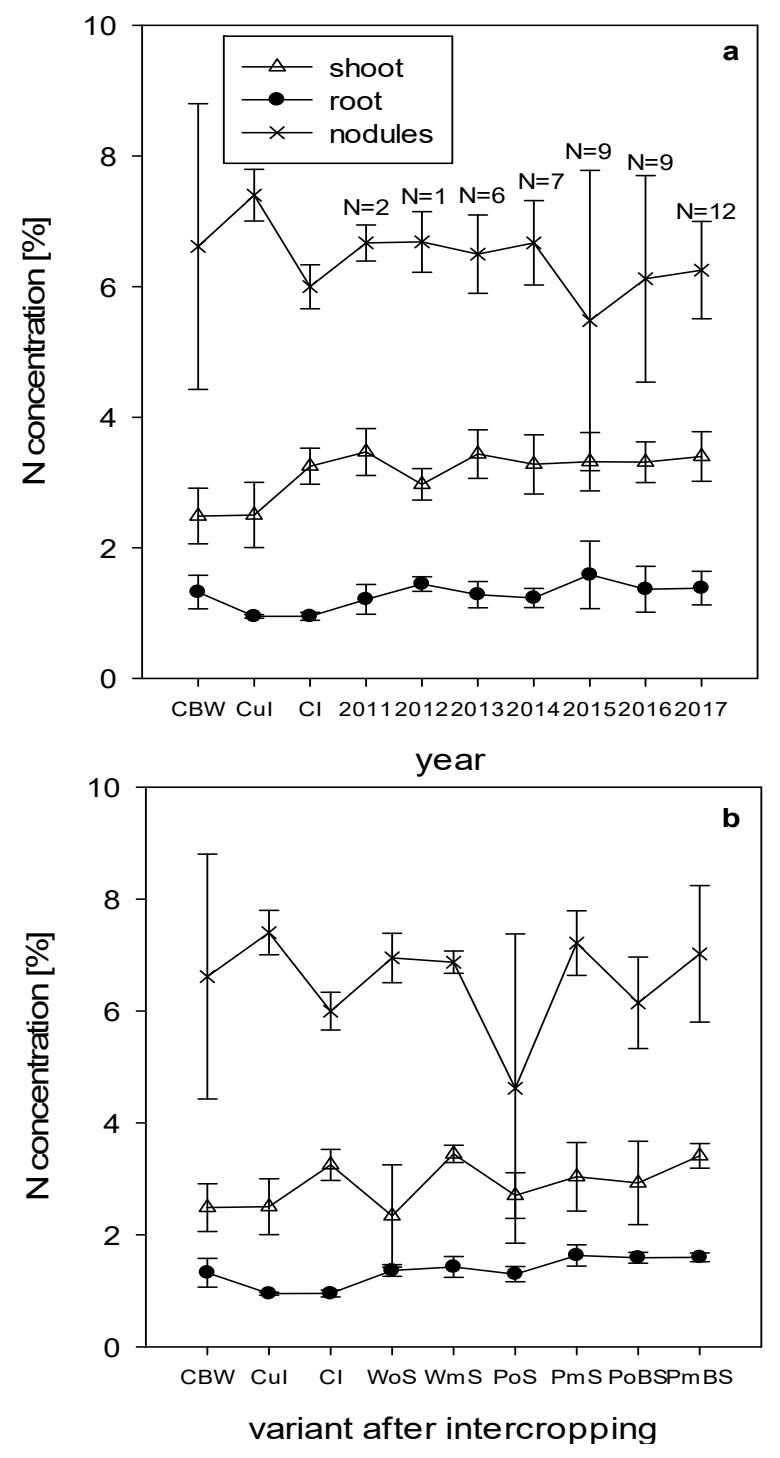

Figure 2. Average nitrogen concentrations $(\mathrm{N})$ in roots, shoots, and nodules of soybean plants one to seven years after the last soybean cultivation (a) and after intercropping (b). Bars indicate the standard deviation (SD); each sample is the mean value of four replicates; $\mathrm{CBW}=$ field control without inoculation; $\mathrm{CuI}=$ control with cultivated soil without inoculation; $\mathrm{CI}=$ control with cultivated soil and inoculation; $\mathrm{W}=$ Wroclaw; $\mathrm{P}=$ Pillnitz; $\mathrm{o}=$ without inoculation; $\mathrm{m}=$ with inoculation; $\mathrm{S}=$ soybean as intercropping; $\mathrm{BS}=$ buckwheat and soybean as intercropping. 
In addition to the $\mathrm{N}$ contents, the $\mathrm{S}$ concentrations in the nodules were also determined (see Figure 3 ). In soil samples from fields where the last soybean cultivation was in the years between 2011 and $2017, \mathrm{~S}$ contents of $0.35 \%$ to $0.48 \%$ were measured. In the samples taken after soybean was used as the intercrop, the values were between $0.23 \%$ and $0.49 \%$. The inoculated variants in Pillnitz showed higher $\mathrm{S}$ concentrations than the uninoculated samples. For the samples in Wroclaw and the control (CuI, CI) the exact opposite was observed. In addition, the $\mathrm{N}$ and $\mathrm{S}$ contents of soybean nodules from the samples where soybean cultivation had last occurred between 2011 and 2017 showed a highly significant correlation $(r=0.72)$ and demonstrated the importance of nutrient availability for nodule formation.

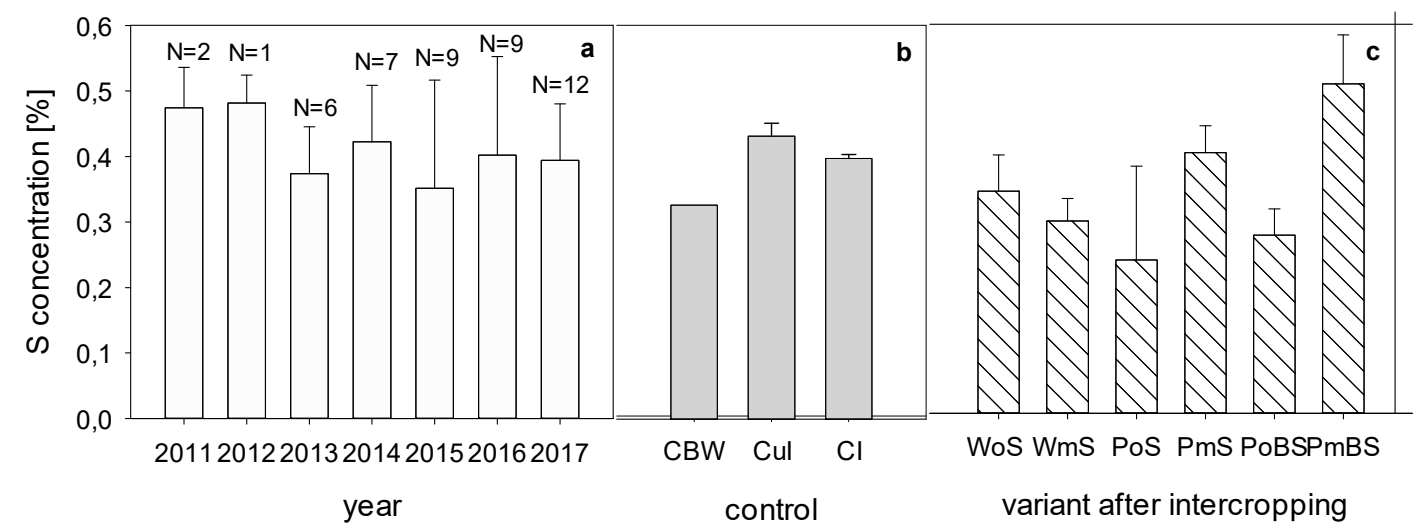

Figure 3. Average sulfur concentration $(S)$ in nodules one to seven years after the last soybean cultivation (a), in control samples (b), and after intercropping (c). Bars indicate the standard deviation (SD); each sample is the mean value of four replicates; $\mathrm{CBW}=$ field control without inoculation; $\mathrm{CuI}=$ control with cultivated soil without inoculation; $\mathrm{CI}=$ control with cultivated soil and inoculation; $\mathrm{W}=$ Wroclaw $; \mathrm{P}=$ Pillnitz; $\mathrm{o}=$ without inoculation; $\mathrm{m}=$ with inoculation; $\mathrm{S}=$ soybean as intercropping; $\mathrm{BS}=$ buckwheat and soybean as intercropping.

The correlation analysis (Table 4) presents the relationship of the nodule number and nodule mass with the root and shoot dry mass, as well as $\mathrm{N}$ concentrations in the individual plant parts. The nodular mass had a stronger influence on shoot development $(r=0.88)$ than the nodule number. The number of nodules had no influence on root development, but a medium correlation can be seen between the nodules and root dry mass $(r=0.54)$. Moreover, the $\mathrm{N}$ concentrations in the roots decrease with increasing numbers of nodules and increasing nodule mass $(r=-0.25, r=-0.36)$. This indicates that nitrogen accumulation in the roots does not increase at the same rate as in the nodules. Due to the strong influence of the nodule mass on the root and shoot dry mass, a dilution of the nitrogen in the roots can be assumed. From the results in Table 4, it can be concluded that the nodule mass has a stronger influence on plant growth than the number of nodules, because the correlations show a stronger relationship. A correlation between grain yield in the soybean harvest year and nodule development (nodular mass $r=-0.0003$; number of nodules $r=0.24$ ) could not be demonstrated.

The soil plant analysis development (SPAD) value reflects the chlorophyll content in the leaves and indicates a better nitrogen supply in the inoculated varieties due to better nodule formation compared to the non-inoculated samples. SPAD values were recorded on three different dates and ranged from 20.6 to 40.9 (1 May), 26.5 to 38.4 (1 June), and 18.0 to 43.2 (16 June). As expected, the lowest value was always observed for the oldest leaf and the highest value for the youngest fully unfolded leaf. This result demonstrates the source-sink relationship and the redistribution of nutrients within the plants. The control plant (CuI), which was not inoculated, always showed the lowest SPAD values. 


\section{Discussion}

The aim of this study was to analyze the presence of soybean-specific rhizobia under Central European conditions, even after a longer interruption of soybean cultivation, in agricultural soils of one to seven years after the last crop. Furthermore, the effects of existing rhizobia on a new soybean crop-and thus on the growth of nodules, roots, and shoots and the $\mathrm{N}$ and $\mathrm{S}$ concentrations in the nodules-were investigated.

\subsection{Presence of Rhizobia in Soil}

The sequence data showed that there were no differences in the relative abundance of Bradyrhizobium sp. in the soil samples after a soybean cultivation break of one to seven years. In addition, studies from France [3,4,6], Poland [2], and USA [23] demonstrated that soybean rhizobia could survive in soil for up to 30 years. There is now also evidence for Germany and southern Poland that Bradyrhizobium sp. was found under the climatic conditions of Central Europe even after seven years in agriculturally used soils, without soybeans being cultivated during this time. Furthermore, the experiment showed that even after a longer soybean cultivation break, the existing rhizobia are able to form a symbiosis with the soybeans and form nodules to fix atmospheric nitrogen. This can be seen from the number of nodules recorded in the different years, which ranged from 21 to 37 nodules per plant. In comparison, the field control (C BW), which was not inoculated, showed only 0.2 nodules per plant (SE \pm 0.25). Since only the genus Bradyrhizobium sp. could be mapped during the sequencing, it must be taken into account that Bradyrhizobia can also be hosted by other legumes, such as lupines. There is evidence of this in Brazil [24], USA [25], and Spain and Chile [26], where Bradyrhizobia was isolated from different lupine species. For the field control (C BW) and the other samples from the Pillnitz experimental station, however, this can be ruled out, as no cultivation with lupines has yet taken place on this site. In the samples from the farms, cultivation with lupines cannot be completely ruled out. Nevertheless, it should be noted that in Germany lupine is preferably cultivated on sandy sites.

\subsection{Influence of Soil Properties on Nodule and Plant Growth}

In this context, the influence of different soil conditions on rhizobia presence and plant growth was also investigated. There were significant results related to the humus and total $\mathrm{N}$ content of soil, which had a weak effect on the numbers of nodules, nodular mass, and $\mathrm{N}$ concentrations of the nodules. However, Lawson et al. [27] confirmed a positive effect of organic matter on plant growth and nodule formation in soybeans under acidic and saline conditions. In addition, the plant-available phosphorus content of the soil seems to have a weak influence on the nodule mass. Singleton et al. [28] and Mullen et al. [29] were able to demonstrate the positive influence of phosphorus in soil on the nodule mass, nodule number, and shoot dry mass. In this context, Mullen et al. [29] found that the influence of phosphorus on plant growth was more obvious than on the B. japonicum nutrition. This is also reflected by the high root and shoot dry masses per plant from the intercrop experiment with soybean and buckwheat. The breakdown of the data by $\mathrm{pH}$ values $<6$ and $>6$ showed only a moderate influence of $\mathrm{pH}$ value $<6$ on root dry mass and nodule number, thus confirming the results from Buendía-Clavería et al. [7] and Revellin et al. [6]. In contrast to other publications, nodule growth in this study appeared to be only marginally influenced by the humus, $\mathrm{N}$, and P contents of the soil, suggesting that even after seven years there are sufficient rhizobia in the soil to form nodules on soybean roots. For the relative abundance of Bradyrhizobium sp. in soil, a different picture was obtained. Here, increasing $\mathrm{pH}$, phosphorus, potassium, and magnesium contents seems to reduce the relative abundance of Bradyrhizobium sp. in the analyzed soil sample. There are differing results in the literature dealing with different issues, but both relevant studies use soil samples from several locations. For example, Weaver et al. [8] found that the soil factors organic matter, soil N, soil P, soil K, and soil texture had no influence on the number of rhizobia. Ham et al. [30], on the other hand, were able to demonstrate a minor influence of soil properties on the occurrence of rhizobia, primarily pointing 
to the influence of the $\mathrm{pH}$ value on the rhizobia. The results of the experiment rather confirm the statements by Ham et al. [30] and show that the soil conditions should not be disregarded in such investigations. In addition, the influence of the $\mathrm{pH}$ value on the uptake of essential nutrients from the soil must be pointed out. Fageria and Baligar [31] were able to show that the dry matter yield of shoots is significantly influenced by the $\mathrm{pH}$ and is at an optimum of 5.6 for soybeans. For cultivation in Germany, on the other hand, slightly acidic to neutral soils ( $\mathrm{pH}$ 6.5-7) are specified as optimum [32]. Differences in shoot dry matter could be seen on the sites with intercropped soybeans in Pillnitz (P), Breslau (Wr), and Waldenburg (W IC) (Table 3). In contrast to Fageria and Baligar [31], however, the shoot dry mass in P (5.0-7.1 g) was the highest at pH 6.9 compared to W IC (5.1 g; pH 5.5) and $\mathrm{Wr}$ (3.8-4.1 g; pH 5.8). For this reason, it is difficult to assess only the influence of the $\mathrm{pH}$ value on plant growth. The remaining nutrient availability at the Pillnitz site was also better than in Breslau and Waldenburg and may have led to better growth. Furthermore, it can be concluded that after an interruption of soybean cultivation, rhizobia for nodule formation are still present in the soil and it is assumed that the relative abundance of Bradyrhizobium sp. could be positively influenced by good nutrient management.

\subsection{Plant Growth and Nutrient Concentration}

In the analysis of the effects of soybean cultivation breaks on nodule growth and dry matter, a significant influence on nodule number and root dry matter could only be observed between the soil samples with the last inoculated soybean cultivation years 2014 and 2017. However, larger differences were found for intercrop varieties. Here, the nodule numbers and root dry matter values were significantly higher in the inoculated varieties. Obaton et al. [4] could detect $10^{3}$ rhizobia $^{-1}$ soil of B. japonicum after a 20-year soybean cultivation break. Weaver and Frederick [33] and Thies et al. [34] confirmed that the number was sufficient for good nodulation and that re-inoculation was not necessary under these conditions. Likewise, Triplett et al. [5] showed no differences in population size for B. japonicum in the field that had not been planted with soybeans for up to four years. The current study suggests that there is no difference in the nodular mass values and numbers of nodules between the samples with different soybean cultivation histories $\left(0.10 \mathrm{~g} \mathrm{plant}^{-1} ; 30.0\right.$ number plant $\left.^{-1}\right)$ and the inoculated varieties from the intercrop experiment $\left(0.13 \mathrm{~g} \mathrm{plant}^{-1} ; 29.4\right.$ number plant $\left.{ }^{-1}\right)$. Only the inoculated control (C I) showed much higher nodules ( 57.7 number plant ${ }^{-1}$ ), but this could not be exploited for stronger plant growth. Only the $\mathrm{N}$ concentrations in the individual plant parts seemed to show that a recent inoculation was more effective. Here, we show that the contents of Bradyrhizobium $\mathrm{sp}$. in the investigated soils were still sufficient after seven years to form the nodules necessary for nitrogen fixation, since nodules were detected in all soil samples on which soybeans were grown between 2011 and 2017.

For the variants with buckwheat, the high root and shoot dry matter values per plant should be noted. Buckwheat seems to have a positive effect on the growth of soybeans by releasing phosphatases, as this increases the phosphorus content of the soil $[35,36]$. This result is also reflected in high nitrogen concentrations in the nodules, and thus partly explains the positive soil effects of soybeans on the subsequent crop [37]. This would also explain the high $\mathrm{N}$ content in the non-inoculated variant with soybeans and buckwheat (Figure $2 \mathrm{~b}$ ). So far, there are hardly any data available on the total $\mathrm{N}$ content of soybean nodules. For example, Streeter [38] published results for the nodule $\mathrm{NO}_{3}{ }^{-}$concentrations and nodule $\mathrm{NO}_{2}{ }^{-}$concentrations ( $\mu \mathrm{g} \mathrm{N} / \mathrm{g}$ fresh weight) of soybean and was able to demonstrate that high $\mathrm{N}$ concentrations have a reducing effect on nodular mass. This is also confirmed by the results of the present study, in which high $\mathrm{N}$ concentrations in soil also had a negative influence on nodule growth. Gates and Müller [39], who studied the nodule and plant growth of soybeans, found that nodule development is strongly responsive to the nutrient combination of N, P, and S, and should be well-balanced. Furthermore, they also showed a correlation between $\mathrm{N}$ and $\mathrm{S}$ in the nodules. Zhao et al. [40] and Gates and Müller [39] stated that the number and mass of nodules can be increased by sulfur. Sulfur is important for the $\mathrm{N}_{2}$ fixation of grain legumes as it influences the 
activity of various central enzymes such as nitrogenase, phosphoenolpyruvate carboxylase, and malate dehydrogenase [41].

Additionally, the influence of the number of nodules and the nodule mass compared to the dry mass development of roots and shoots was investigated, as well as the nitrogen concentration in the individual plant parts, showing that the nodular mass had a stronger influence on the individual parameters compared to the number of nodules. Therefore, the development of large nodules should be enhanced. The formation and maintenance of nodules is energy-intensive, which is why a plant must weigh up the extent to which it uses resources for this purpose. It can, therefore, be assumed that plants with good nodule and plant growth have a good nutrient supply. In contrast, the excessive growth of nodules would lead to loss of yield because the balance would be disturbed [42]. In this context, Li et al. [43] showed that an overexpression of the gene GmINS1 leads to an increase in the nodule number, biomass, and nitrogenase activity of large nodules. Peng et al. [44] observed an increase in nodular mass when magnesium was added under nitrogen-limited conditions, as well as an improved $\mathrm{N}_{2}$ fixation performance of the nodules, which can be attributed to a changed carbohydrate distribution. Moreover, Ohyama et al. [45] described a decrease in nodular mass with additional nitrate fertilization compared to the control. The present study also showed a negative, significant mean correlation between the nodule mass and nitrogen content in soil $(\mathrm{r}=-0.31)$. In contrast to Peng et al. [44], however, the magnesium content of the soil samples had no influence on nodule growth $(r=-0.11)$. From these results, it can be concluded that buckwheat had a positive influence on soybean nodule formation, probably due to the higher availability of phosphorus in the soil, which in turn contributes significantly to the increase in shoot and root dry matter.

During the course of the experiment, it became apparent that it is difficult to establish an adequate control for this type of experiment, since a small number of nodules was also formed in the controls, although they had not been previously exposed to inoculant or soybean seeds. Furthermore, it would have made sense to sterilize the peat before use. Nevertheless, it cannot be excluded that these are caused by air turbulence or tap water, although the samples were handled with great care to avoid contamination. Andersson [46] and Obaton et al. [4] confirmed in their work that cross-contamination between samples is a problem. In addition, the non-inoculated variant in the study by Indrasumunar et al. [47] showed a low number of nodules. On the other hand, these results showed that even in non-inoculated soils in eastern parts of Germany and Lower Silesia in Poland, native rhizobia occur, which can form a symbiosis with soybeans and successfully form nodules. Mądrzak et al. [48] also proved this with their study in Poland. The persistence of soybean-specific rhizobia by other legume hosts such as weeds or lupines must also be investigated. Therefore, the bacteria should be further specified in future work by PCR. With a total of 17 samples, the sample size for sequencing was comparatively small and should be extended in further studies to statistically confirm the presented results.

In conclusion, the study contributes to clarifying the current situation in East Germany and Lower Silesia, where soybean cultivation has only increased in importance in the last ten years. Furthermore, data on $\mathrm{N}$ and $\mathrm{S}$ contents in soybean nodules are scarce. Moreover, the genetic analyses of the soil samples give an overview of the persistence of Bradyrhizobium sp. Even after an interruption in soybean cultivation of up to seven years, there were still nodule bacteria in the soil, which entered into a symbiosis with the soybean plants without showing differences in plant growth. Based on these results, after an initial inoculation of the seeds and with regular soybean cultivation, further inoculation seems not be necessary. 
Supplementary Materials: The following are available online at http://www.mdpi.com/2077-0472/10/10/446/s1: Figure S1: Microbial diversity of selected soil samples. Shown are the relative abundances of detected genera. The microbial community was analyzed by amplifying and sequencing the V4 region of the 16S rRNA gene via MiSeq Illumina. The respective sequence data are available under the bioproject accession number PRJNA663446. Table S1: Detected Bradyrhizobium OTUs. Operational taxonomic units (OTUs) consist of defined and assembled taxa. The use of OUTs is widely accepted and applied to describe bacterial communities using amplicon sequencing of 16S rRNA gene". For more information, please visit the rtl-genomics webpage (www.rtlgenomics.com/docs/ Data_Analysis_Methodology.pdf).

Author Contributions: Conceptualization, K.S. and A.G.; methodology, A.G., N.M. and K.S.; formal analysis, A.G. and N.M.; resources, A.G., S.L. and K.S.; writing original draft preparation, A.G.; visualization, A.G.; supervision, S.L. and K.S.; writing review and editing, A.G., N.M., S.L. and K.S.; All authors have read and agreed to the published version of the manuscript.

Funding: This research was funded by the European Social Fund and Sächsische Aufbaubank, grant number 100327910. This article was funded by the Open Access Publication Fund of Hochschule für Technik und Wirtschaft Dresden University of Applied Sciences and the Deutsche Forschungsgemeinschaft (DFG, German Research Foundation)—432908064.

Acknowledgments: The authors acknowledge all participating farmers for their cooperation and support in taking samples in spring 2018. Special thanks also go to Annika Eisenschmidt, who was always available with help and advice and took over the final correction at short notice, as well as to Marcel Porte for his patience during the preparation of the work.

Conflicts of Interest: The authors declare that they have no conflict of interest.

\section{References}

1. Bundesministerium für Ernährung und Landwirtschaft (BMEL). Ernte 2019. Mengen und Preise; BMEL: Berlin, Germany, 2019; pp. 15-16. Available online: https://www.bmel.de/SharedDocs/Downloads/DE/ _Landwirtschaft/Pflanzenbau/Ernte-Bericht/ernte-2019.html (accessed on 30 March 2020).

2. Narożna, D.; Pudełko, K.; Króliczak, J.; Golińska, B.; Sugawara, M.; Mądrzak, C.J.; Sadowsky, M.J. Survival and competitiveness of Bradyrhizobium japonicum strains 20 years after introduction into field locations in Poland. Appl. Environ. Microbiol. 2015, 81, 5552-5559. [CrossRef] [PubMed]

3. Brunel, B.; Cleyet-Marel, J.C.; Normand, P.; Bardin, R. Stability of Bradyrhizobium japonicum inoculants introduced into soil. In Nitrogen Fixation: Hundred Years After; Bothe, H., de Bruijn, F.J., Newton, W.E., Eds.; Fischer: Stuttgart, Germany, 1988; p. 780.

4. Obaton, M.; Bouniols, A.; Guillaume, P.; Guillaume, P.; Vadez, V. Are Bradyrhizobium japonicum stable during a long stay in soil? Plant Soil 2002, 245, 315-326. [CrossRef]

5. Triplett, E.W.; Albrecht, K.A.; Oplinger, E.S. Crop rotation effects on populations of Bradyrhizobium japonicum and Rhizobium meliloti. Soil Biol. Biochem. 1992, 25, 781-784. [CrossRef]

6. Revellin, C.; Pinochet, X.; Beauclair, P.; Catroux, G. Influence of soil properties and soybean cropping history on the Bradyrhizobium japonicum population in some French Soils. Eur. J. Soil Sci. 1996, 47, 505-510. [CrossRef]

7. Buendía-Clavería, A.; Rodriguez-Navarro, D.; Santamaría-Linaza, C.; Ruiz-Saínza, J.; Temprano-Vera, F. Evaluation of the symbiotic properties of Rhizobium fredii in European soils. System. Appl. Microbiol. 1994, 17, 155-160. [CrossRef]

8. Weaver, R.W.; Frederick, L.R.; Dumenil, L.C. Effect of soybean cropping and soil properties on numbers of Rhizobium japonicum in Iowa soils. Soil Sci. 1972, 114, 137-141. [CrossRef]

9. Zhang, H.; Prithiviraj, B.; Charles, T.C.; Driscoll, B.T.; Smith, D.L. Low temperature tolerant Bradyrhizobium japonicum.strains allowing improved nodulation and nitrogen fixation of soybean in a short season (cool spring) area. Eur. J. Agron. 2003, 19, 205-213. [CrossRef]

10. Suzuki, Y.; Adhikari, D.; Itoh, K.; Suyama, K. Effects of temperature on competition and relative dominance of Bradyrhizobium japonicum and Bradyrhizobium elkanii in the process of soybean nodulation. Plant Soil 2014, 374, 915-924. [CrossRef]

11. Association of German Agricultural Analytic and Research Institutes e. V. (VDLUFA). Methode A 5.1.1: Bestimmung des $\mathrm{pH}$-Wertes. In Handbuch der Landwirtschaftlichen Versuchs- und Untersuchungsmethodik (VDLUFA-Methodenbuch); Bd. I Die Untersuchung von Böden; 7. Teillfg. 2016; VDLUFA-Verlag: Darmstadt, Germany, 1991. 
12. Association of German Agricultural Analytic and Research Institutes e. V. (VDLUFA). Methode A 6.2.1.1: Bestimmung von Phosphor und Kalium im Calcium-Acetat-Lactat-Auszug. In Handbuch der Landwirtschaftlichen Versuchs- und Untersuchungsmethodik (VDLUFA-Methodenbuch); Bd. I Die Untersuchung von Böden; 6. Teillfg. 2012; VDLUFA-Verlag: Darmstadt, Germany, 1991.

13. Association of German Agricultural Analytic and Research Institutes e. V. (VDLUFA). Methode A 6.2.4.1: Bestimmung des pflanzenverfügbaren Magnesiums im Calciumchlorid-Auszug. In Handbuch der Landwirtschaftlichen Versuchs- und Untersuchungsmethodik (VDLUFA-Methodenbuch); Bd. I Die Untersuchung von Böden; VDLUFA-Verlag: Darmstadt, Germany, 1991.

14. DIN EN 15936:2012-11 Schlamm, Behandelter Bioabfall, Boden und Abfall-Bestimmung des Gesamten Organischen Kohlenstoffs (TOC) Mittels Trockener Verbrennung; Beuth Verlag: Berlin, Germany, 2012.

15. LKS LMUAA 027 Bestimmung des Gesamtstickstoffs in Böden durch Verbrennung und Gasanalyse. In DAkkS Anlage zur Akkreditierungsurkunde D-PL-14632-01-00 nach DIN EN ISO/IEC 17025:2018; Landwirtschaftliche Kommunikations- und Service- gesellschaft mbH (LKS): Amberg, Germany, 2019.

16. DIN ISO 11277:2002-08 Bodenbeschaffenheit_Bestimmung der Partikelgrößenverteilung in Mineralböden-Verfahren Mittels Siebung und Sedimentation; ISO 11277: 1998/Cor.1:2002; Beuth Verlag: Berlin, Germany, 2002.

17. Sächsisches Landesamt für Umwelt und Geologie Bodenatlas des Freistaates Sachsen Teil 2: Standortkundliche Verhältnisse und Bodennutzung. Lößnitz-Druck GmbH: Radebeul, Germany, 1996. Available online: https://www.umwelt.sachsen.de/umwelt/download/boden/Bodenatlas-Teil2.pdf (accessed on 20 May 2020).

18. Geologischer Dienst NRW Einteilung der Bodenarten; Geologischer Dienst Nordrhein-Westfalen Krefeld: Krefeld, Germany, 2019; pp. 3-4. Available online: https://www.landwirtschaftskammer.de/lufa/pdf/bodenarteneinteilung.pdf (accessed on 20 May 2020).

19. Link, M.; Vorderbrügge, T.; Michalski, A.; Kowalkowski, A.; Harrach, T. Interpretation of German and Polish soil assessment data in order to deduce and to evaluate soil parameters and functions. Die Bodenkult. 2010, $61,11-24$.

20. Mullis, K.; Faloona, F.; Scharf, S.; Saiki, R.; Horn, G.; Erlich, H. Specific enzymatic amplification of DNA in Vitro: The Polymerase Chain Reaction. Cold Spring Harb. Symp. Quant. Biol. 1986, 51, 263-273. [CrossRef] [PubMed]

21. Caporaso, J.G.; Lauber, C.L.; Walters, W.A.; Berg-Lyons, D.; Lozupone, C.A.; Turnbaugh, P.J.; Fierer, N.; Knight, R. Global Patterns of 16S RRNA Diversity at a Depth of Millions of Sequences per Sample. Proc. Natl. Acad. Sci. USA 2011, 108, 4516-4522. [CrossRef] [PubMed]

22. RTLGenomics. Available online: https://www.ncbi.nlm.nih.gov/ (accessed on 15 September 2020).

23. Kamicker, B.J.; Brill, W.J. Methods to alter the recovery and nodule location of Bradyrhizobium japonicum inoculant strains on field-grown soybeans. Appl. Environ. Microbiol. 1987, 53, 1737-1742. [CrossRef] [PubMed]

24. Granada, C.; Vargas, L.; Hayashi Sant'Anna, F.; Balsanelli, E.; Antonio de Baura, V.; de Oliveira Pedrosa, F.; Maltempi de Souza, E.; Falcon, T.; Passaglia, L. The genomes of three Bradyrhizobium sp. isolated from root nodules of Lupinus albescens grown in extremely poor soils display important genes for resistance to environmental stress. Genet. Mol. Biol. 2018, 41, 502-506. [CrossRef] [PubMed]

25. Ehinger, M.; Mohr, T.J.; Starcevich, J.B.; Sachs, J.L.; Porter, S.; Simms, E. Specialization-generalization trade-off in a Bradyrhizobium symbiosis with wild legume hosts. BMC Ecol. 2014, 14, 8. [CrossRef]

26. Velázquez, E.; Valverde, A.; Rivas, R.; Gomis, V.; Peix, A.; Gantois, I.; Igual, J.M.; León-Barrios, M.; Willems, A.; Mateos, P.F.; et al. Strains nodulating Lupinus albus on different continents belong to several new chromosomal and symbiotic lineages within Bradyrhizobium. Antonie Van Leeuwenhoek 2010, 97, 363-376. [CrossRef]

27. Lawson, Y.D.; Muramatsu, K.; Nioh, I. Effect of organic matter on the growth, nodulation, and nitrogen fixation of soybean grown under acid and saline conditions. Soil Sci. Plant Nutr. 1995, 41, 721-728. [CrossRef]

28. Singleton, P.W.; Abdel Magid, H.M.; Tavares, J.W. Effect of phosphorus on the effectiveness of strains of Rhizobium japonicum. Soil Sci. Soc. Am. J. 1985, 49, 613-616. [CrossRef]

29. Mullen, M.D.; Israel, D.W.; Wollum, A.G. Effects of Bradyrhizobium japonicum and Soybean (Glycine max (L.) Merr.) Phosphorus Nutrition on Nodulation and Dinitrogen Fixation. Appl. Environ. Microbiol. 1988, 54, 2387-2392. [CrossRef]

30. Ham, G.E.; Frederick, L.R.; Anderson, I.C. Serogroups of Rhizobium japonicum in Soybean Nodules Sampled in Iowa. Agron. J. 1971, 63, 69-72. [CrossRef] 
31. Fageria, N.K.; Baligar, V.C. Growth and nutrient concentrations of common bean, lowland rice, corn, soybean, and wheat at different soil ph on an inceptisol. J. Plant Nutr. 1999, 22, 1495-1507. [CrossRef]

32. Unsleber, J.; Kreikenbohm, C.; Schätzl, R.; Braun, S.; Nadler, C.; Reindl, A. Soja-Anbau und Verwertung; Bayerische Landesanstalt für Landwirtschaft (LfL): Freising-Weihenstephan, Germany, 2018.

33. Weaver, R.W.; Frederick, L.R. Effect of Inoculum Rate on Competitive Nodulation of Glycine max L. Merrill. II. Field Studies. Agron. J. 1974, 66, 233. [CrossRef]

34. Thies, J.E.; Singleton, P.W.; Bohlool, B.B. Influence of the Size of Indigenous Rhizobial Populations on Establishment and Symbiotic Performance of Introduced Rhizobia on Field-Grown Legumes. Appl. Environ. Microbiol. 1991, 57, 19-28. [CrossRef]

35. Amann, C.; Amberger, A. Phosphorus Efficiency of Buckwheat (Fagopyrum esculentum). J. Plant Nutr. Soil Sci. 1989, 152, 181-189. [CrossRef]

36. Possinger, A.R.; Byrne, L.B.; Breen, N.E. Effect of buckwheat (Fagopyrum esculentum) on soil-phosphorus availability and organic acids. J. Plant Nutr. Soil Sci. 2013, 176, 16-18. [CrossRef]

37. DeMooy, C.J.; Pesek, J.; Spaldon, E. Mineral nutrition in Soybeans: Improvement, Production and Uses. Am. Soc. Agron. Madison Wis. 1973, 16, 267-352.

38. Streeter, J.D. Synthesis and Accumulation of Nitrite in Soybean Nodules Supplied with Nitrate. Plant Physiol. 1982, 69, 1429-1434. [CrossRef]

39. Gates, C.T.; Müller, W.J. Nodule and Plant Development in the Soybean, Glycine max (L.) Merr. Growth Response to Nitrogen, Phosphorus and Sulfur. Aust. J. Bot. 1979, 27, 203-215. [CrossRef]

40. Zhao, Y.; Xiao, X.; Bi, D.; Hu, F. Effects of Sulfur Fertilization on Soybean Root and Leaf Traits, and Soil Microbial Activity. J. Plant Nutr. 2008, 31, 473-483. [CrossRef]

41. Lange, A. Influence of S Supply on the Biological Nitrogen Fixation of Legumes. Ph.D. Thesis, University of Bonn, Bonn, Germany, 1998.

42. Ferguson, B.J. The Development and Regulation of Soybean Nodules. In A Comprehensive Survey of International Soybean Research, Genetics, Physiology, Agronomy and Nitrogen Relationships; Board, J., Ed.; InTech: Rijeka, Croatia, 2013.

43. Li, X.; Zheng, J.; Yang, Y.; Liao, H. Increasing Nodule Size1 Expression is Required for Normal Rhizobial Symbiosis and Nodule Development. Plant Physiol. 2018, 178, 1233-1248. [CrossRef]

44. Peng, W.T.; Zhang, L.D.; Zhou, Z.; Fu, C.; Chen, Z.C.; Liao, H. Magnesium promotes root nodulation through facilitation of carbohydrate allocation in soybean. Physiol. Plant. 2018, 163, 372-385. [CrossRef]

45. Ohyama, T.; Fujikake, H.; Yashima, H.; Tanabata, S.; Ishikawa, S.; Sato, T.; Fujimaki, S. Effect of Nitrate on Nodulation and Nitrogen Fixation of Soybean. In Soybean Physiology and Biochemistry; El-Shemy, H., Ed.; InTech: Rijeka, Croatia, 2011; pp. 333-364. Available online: http://www.intechopen.com/books/soybeanphysiologyand-biochemistry/effect-of-nitrate-on-nodulation-and-nitrogen-fixation-of-soybean (accessed on 20 May 2020).

46. Andersson, E. Need for Seed Re-Inoculation in Swedish Soybean Cropping Sequences; Second Cycle. A2E, SLU; Department of Soil and Environment: Uppsala, Sweden, 2014; Available online: http://urn.kb.se/resolve? urn=urn:nbn:se:slu:epsilon-s-4047 (accessed on 21 August 2017).

47. Indrasumunar, A.; Menzies, N.W.; Dart, P.J. Laboratory prescreening of Bradyrhizobium japonicum for low $\mathrm{pH}$, $\mathrm{Al}$ and Mn tolerance can be used to predict their survival in acid soils. Soil Biol. Biochem. 2012, 48, 135-141. [CrossRef]

48. Mądrzak, C.J.; Golińska, B.; Króliczak, J.; Pudełko, K.; Łażewska, D.; Lampka, B.; Sadowsky, M.J. Diversity among Field Populations of Bradyrhizobium japonicum in Poland. Appl. Environ. Microbiol. 1995, 61, 1194-1200. [CrossRef] [PubMed]

(C) 2020 by the authors. Licensee MDPI, Basel, Switzerland. This article is an open access article distributed under the terms and conditions of the Creative Commons Attribution (CC BY) license (http://creativecommons.org/licenses/by/4.0/). 